\title{
GROUNDWATER EXPLORATION USING FUZZY LOGIC APPROACH IN GIS FOR AN AREA AROUND AN ANTICLINE, FARS PROVINCE
}

\author{
S. Rafati a ${ }^{*}$, M. Nikeghbal ${ }^{\text {b }}$ \\ ${ }^{a}$ Dept. of Geography, Sayyed Jamaleddin Asadabadi University, Assadabad, Hamedan, Iran- rafati@ sjau.ac.ir \\ ${ }^{\mathrm{b}}$ Master of Geography, Tarbiat Modares University, Tehran, Iran- nikegbal.m@ gmail.com
}

KEY WORDS: ground water, explore, fuzzy gamma, anticline

\begin{abstract}
:
In the recent years, the over-use of water resource due to the population growth and industrial developing has become serious. With attention to demand for water, it's essential to explore and evaluate new water resource and mapping its potential. In this paper, a fuzzy set theory, as a knowledge driven approach for map combination, was applied to produce a potential map for ground water resources. To achieve this objective, a variety of spatial data including geology, slope, elevation, drainage, fault and joint were complied. Then fuzzy membership functions were evaluated for each data layer. These data were integrated using the fuzzy $\gamma$ operator with a value of $\gamma=0.95$. The final map indicates Quaternary formation consists of alluvial deposits near the 200 meter distance from the anti-cline as a suitable area for groundwater resource. Finding out an accurate method which accelerates processing for determining the location of groundwater before drilling is an effective solution leading to save budget and time.
\end{abstract}

\section{INTRODUCTION}

The total amount of water on Earth is 1.4 billion $\mathrm{Km}^{3}$, but only around $41.000 \mathrm{~km}^{3}$ circulates through the hydrological cycle (Acreman, 2000), falling as rain or snow, infiltrating into the soil, flowing as rivers to the sea and evaporating. Only $2.5 \%$ of the Earth's total water resources are freshwater, of which as little as $0.5 \%$ is directly usable; the rest being ice and glaciers (UNEP, 2002). With the increasing demands for water due to increasing population, urbanization and agricultural expansion, groundwater resources are gaining much attention, particularly in arid and semi-arid climatic zone, which faces acute shortages of water throughout the year. A great part of Iran is characterized as an arid and semi-arid region which groundwater in most of these regions is the only water resource, due to very unevenly spatially and temporally distribution of water resource. Groundwater occurs beneath essentially every spot on the Earth, finding usable supplies can be a challenge. Groundwater exploration is an effective technique to compensate the pressure result by lack of surface water in dry climate zone. Exploration of water resource especially underground is a complex set of collecting data, assessment of a suitable methodology, analysis, examination and exploration which needs highly cost supplements. Several studies have been carried out for determination of most suitable area for ground water resource by a variety of methods in the most arid of the world such as artificial recharge (Krishnamurthy et al., 1995; Han, 2003; Ghayoumian et al., 2007) the identification of suitable sites for flood spreading as an artificial groundwater recharge technique (Ghayoumian et al, 2005).

So finding out an accurate method which accelerates processing for determining the location of groundwater before drilling is a cost-effectiveness solution leading a greater part of budget to the other sections of project. GIS application in water resource evaluation has recently expanded with increasing emphasis in surface and subsurface applications (Maidment, 1991; Moore et al., 1991). GIS is a powerful tool to collect and store data, processing and making an appropriate output which would be useful to manage time and cost in most of projects. There are many types of GIS model such as Boolean Logic, Index Overlay, Fuzzy Logic and , ... that related to the purpose of the project can be used effectively. Because of imprecise and uncertainly, ambiguous data or relationships among data sets, fuzzy logic and fuzzy sets have been applied in a wide range of ecological and environmental issues, including environmental impact evaluation (Enea et al., 2001), prediction and modeling of soil erosion (Nisar et al., 2000; Mitra et al., 1998), crop-land suitability (Nisar et al., 2000), assessing spatial and temporal change of salinity (Metternicht., 2001), modeling of time-series of atmospheric pollution (Nunnari et al.,1998), modeling the spatial distribution and species density of vegetation (Kampichler et al., 2000), spatial prediction of landslide hazard (Gorsevski et al., 2003), and mineral exploration (Zadeh, 1965). Many of the fuzzy expert systems discussed in these work to integrate scientific and local knowledge expert about the phenomenon. In fuzzy logic, fuzzy quantifiers such as "likely" and "usually" are treated as fuzzy numbers that represent imprecisely, the absolute or relative count of elements in a fuzzy set (Tangestani et al., 2003). Fuzzy logic was chosen in this research because of its qualification rather than the Boolean logic.

\section{STUDY AREA}

The study area is the region around an anti-cline which located in the 15 kilometer of southeast of Haji Abad city in the Fars province. The area is bounded by latitude $27^{\circ} 55^{\prime}$ to $28^{\circ} 25^{\prime} \mathrm{N}$ and longitude $54^{\circ} 24^{\prime}$ to $55^{\circ} 20^{\prime} \mathrm{E}$, as shown in Figure 1 . It has an arid and semi-arid climate with annual rainfall less than $250 \mathrm{~mm}$ while the evaporation is more than $2600 \mathrm{~mm}$. Mean temperature

\footnotetext{
* Corresponding author
} 
is about $21-24{ }^{\circ} \mathrm{C}$. The anti-cline axis lies in the Zagros Folded Belt with a NW-SE trend. Most of the area is occupied by Quaternary alluvial deposits. The mountains to the north are formed mainly of Jahrum formation and the mountains around the anti-cline formed of resistant formation of Asmari-Jahrum.

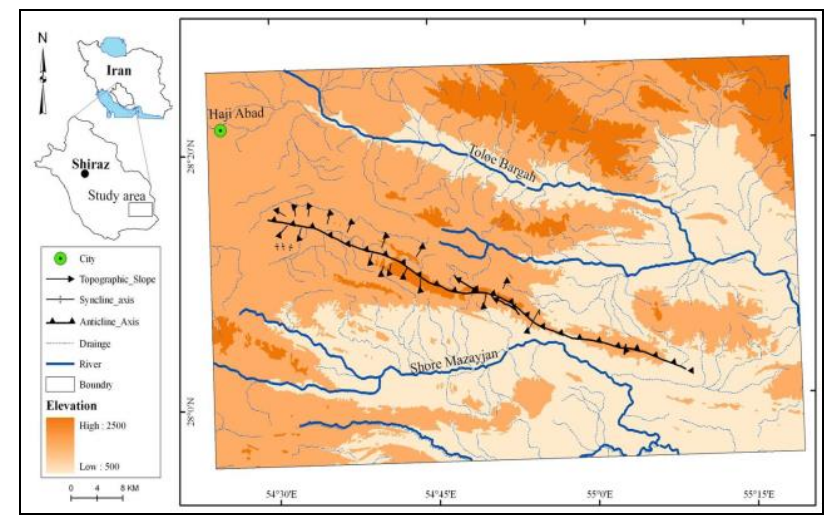

Figure1. Geographical location of study area

\section{METHODS}

\subsection{Fuzzy system}

The main purpose of this research is exploration of groundwater resource using fuzzy logic approach. A fuzzy system is composed of three primary elements namely fuzzy sets, fuzzy membership and fuzzy production rules (Klein, 1999). The fuzzy set theory was introduced by Zadeh (1965), which facilities analysis of non-discrete natural processes or phenomena as mathematical formula (Zimmermann, 1996). It consists of objects and their respective grades of membership in this set. The membership grade of an object is range between 0 and 1 (Assimakopoulos et al., 2003). A fuzzy subset A of $X$ is characterized by a membership function $\mu_{\mathrm{A}}:(\chi) \longrightarrow[0,1]$, which associates with each element $\mathrm{x}$ of $\mathrm{X}$ a number $\mu_{\mathrm{A}}(\chi)$ representing the grade of membership of $x$ in A. The value of 1 denotes full membership and the closer the value is to 0 the weaker is the object's membership in the fuzzy set (Kollias et al., 1998). Each data layer denoted from fuzzy theory can be integrated by using fuzzy operators. In a combination of two membership functions $\mu_{\mathrm{A}}(\chi)$ and $\mu_{\mathrm{B}}(\chi)$, some useful fuzzy sets operators can be used such as union (And), intersection (Or), product, complement (Not), power and join (weighted sum). Production rules represent human knowledge in the form of 'if-then' logical statements. However, expert systems rely on binary logic and probability to develop the inferences used in the production rules. Fuzzy sets allow incorporating vagueness into the production rules since they represent less precise linguistic terms. The logical processing using fuzzy sets is known as fuzzy logic (Klein, 1999).

\subsection{DATA}

Data is a necessity in the all projects, so we process 3 steps relevant to objective of study, consists of spatial data base building, data processing, data integration in the first steps of project.

\subsubsection{Spatial data building}

Evaluation and exploration for water resource is the primary purpose of this study. The important step in the most GIS project is building spatial data base. To do so, we compiled and collected data layers from various source, relating to projects purpose. The primary data layers were generated based on the topographic maps with scale 1:25000 produced by the National Cadastre Centre of Iran to build up a DEM (Digital Elevation Model), and Geological data derived from a geological map of area, complied by National Geological organization at the scale of 1:100000. Slope steepness was calculated of a raster grid cell of $50 \times 50 \mathrm{~m}$ based on the DEM. the slopes were re-classified in to 8 categorizes (Fig.2). Also, the built DEM were used to generate Elevation range with 100 meter intervals. The elevation range was re-classified into 5 categories. As figure 1 shows in the area elevation verified from 500 meter mostly in the southeast to 2500 meter in the northeast. Drainage layer was derived from the topographic maps which was used to generate drainage density (Fig.3) and classified into 8 ranging from less than $1 \mathrm{~km} / \mathrm{km} 2$ to more than $8 \mathrm{~km} / \mathrm{km} 2$ density. As it can be shown in the figure 4 most of the area around the anti-cline has less than $2 \mathrm{~km} / \mathrm{km} 2$ density and only a small area has $7-8 \mathrm{~km} /$ $\mathrm{km} 2$ density. The geological map of study area was digit and the lithological units generated as a formation layer. The fracture and fault have been prepared by digitizing paper based on a 1:100,000 map of geology (Fig 4). The fracture layer was used to create separate buffers with 200 meter interval distance from the major fractures and faults (Fig 5).

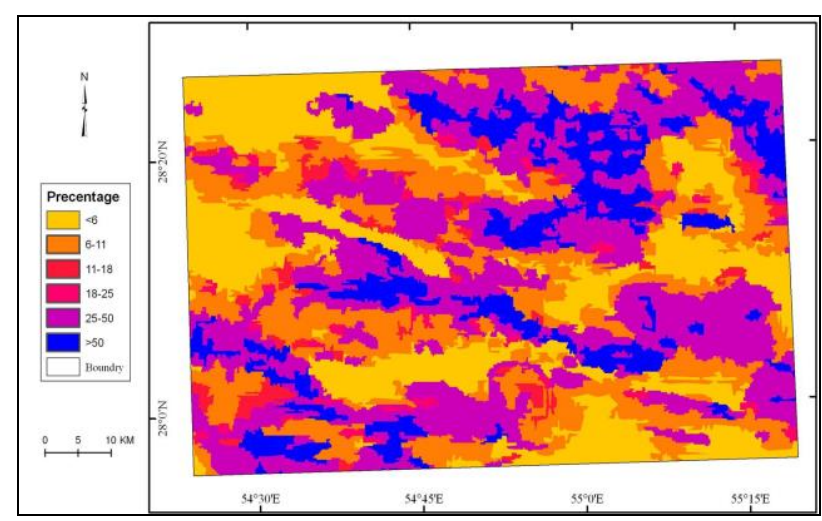

Figure 2. Slope map of study area

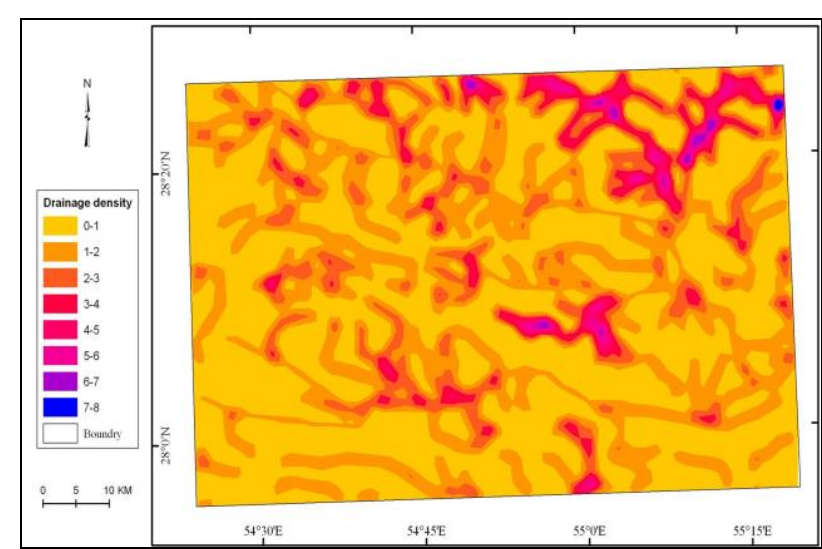

Figure 3. Drainage density of study area 


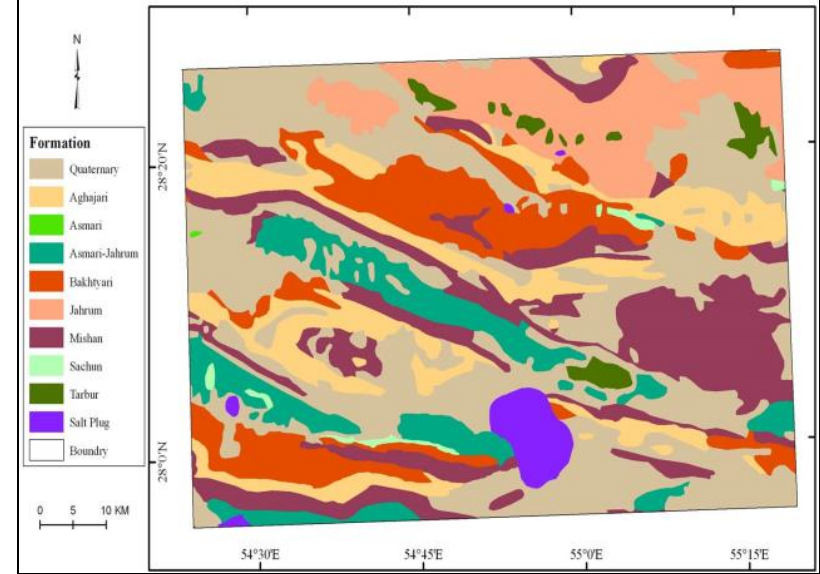

Figure 4. Lithology map of study area

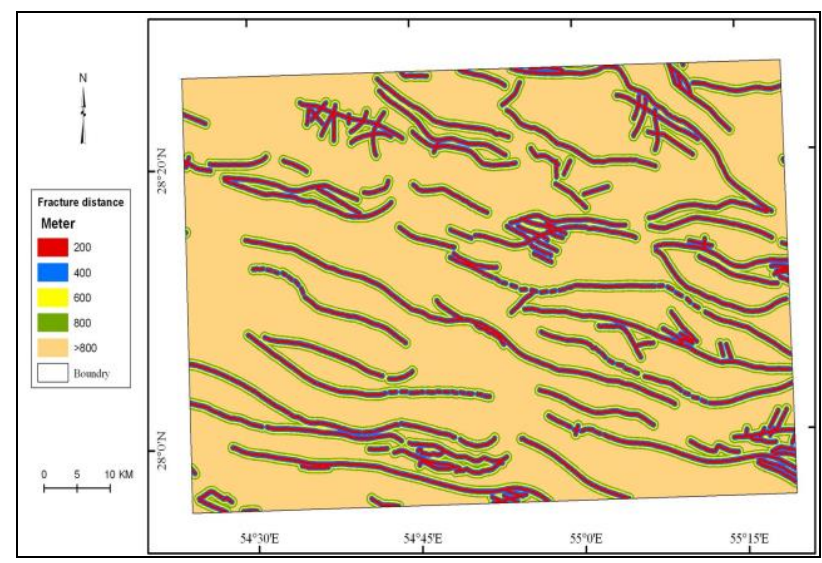

Figure 5. Fracture distance of study area

\subsection{Data processing}

To evaluate the weighting factors to be assign to data layer in accordance with the importance of each class governing the ground water resource, an expert opinion on ecological condition of ground water supplement were considered. So, a membership function as a value between 0 and 1 were assign to each class of every layer according to its effect on ground water supplement exploration. For instance, in the Geology layer regards to its characteristic such as lithology and texture, Quaternary formation consist of recent Alluvial Deposits that has efficient texture for infiltration, among the other formation the greatest value "1" assigned to it. Other formation and lithology evaluated based on their infiltration and get a value. This weighing methodology eases for all layers are presented in the table 1 .

\begin{tabular}{|c|c|c|}
\hline Parameter & Class & $\begin{array}{c}\text { Fuzzy } \\
\text { membership }\end{array}$ \\
\hline \multirow{4}{*}{ Slope (\%) } & $<6$ & 1 \\
\cline { 2 - 3 } & $6-11$ & 0.85 \\
\cline { 2 - 3 } & $11-18$ & 0.73 \\
\cline { 2 - 3 } & $18-25$ & 0.42 \\
\cline { 2 - 3 } & $25-50$ & 0.31 \\
\cline { 2 - 3 } & $>50$ & 0.16 \\
\hline \multirow{4}{*}{$\begin{array}{c}\text { Elevation } \\
\text { range (m) }\end{array}$} & 500 & 1 \\
\cline { 2 - 3 } & 1000 & 0.75 \\
\cline { 2 - 3 } & 1500 & 0.52 \\
\cline { 2 - 3 } & 2000 & 0.3 \\
\hline Fracture & 2500 & 0.1 \\
\hline
\end{tabular}

\begin{tabular}{|c|c|c|}
\hline $\begin{array}{c}\text { distance } \\
(\mathrm{m})\end{array}$ & $\begin{array}{c}200- \\
400\end{array}$ & 0.84 \\
\cline { 2 - 3 } & $400-$ & 0.45 \\
& 600 & \\
\cline { 2 - 3 } & $600-$ & 0.28 \\
& 800 & \\
\cline { 2 - 3 } & $>800$ & 0.1 \\
\hline \multirow{4}{*}{ Drainage } & $0-1$ & 1 \\
\cline { 2 - 3 } density & $1-2$ & 0.97 \\
\cline { 2 - 3 }$\left(\mathrm{km} / \mathrm{km}^{2}\right)$ & $2-3$ & 0.85 \\
\cline { 2 - 3 } & $3-4$ & 0.65 \\
\cline { 2 - 3 } & $4-5$ & 0.5 \\
\cline { 2 - 3 } & $5-6$ & 0.45 \\
\cline { 2 - 3 } & $6-7$ & 0.34 \\
\cline { 2 - 3 } & $7-8$ & 0.12 \\
\hline
\end{tabular}

Table1. Fuzzy membership function for data sets

\begin{tabular}{|c|c|c|c|}
\hline Formation & Symbol & Lithology & fuzzy \\
\hline AghaJari & $\mathrm{Aj}$ & Sandstone, Marl & 0.66 \\
\hline Asmari & As & Limestone & 0.78 \\
\hline $\begin{array}{c}\text { Asmari- } \\
\text { Jahrum(slump) }\end{array}$ & As-Ja1 & Limestone & 0.75 \\
\hline Bakhtiari & $\mathrm{Bk}$ & Conglomerates & 0.96 \\
\hline $\begin{array}{l}\text { Champeh } \\
\text { member }\end{array}$ & Cpm & $\begin{array}{c}\text { Marly } \\
\text { Limestone, } \\
\text { Dolomite }\end{array}$ & 0.54 \\
\hline Chehel member & Chm & Limestone & 0.74 \\
\hline Guri Member & Grm & Limestone, Marl & 0.73 \\
\hline Gurpi & $\mathrm{Gu}$ & $\begin{array}{c}\text { Marl, Shale, } \\
\text { Marly Limestone }\end{array}$ & 0.42 \\
\hline Mishan & $\mathrm{Mn}$ & Marl, Limestone & 0.73 \\
\hline Mole member & Mlm & Marl, Limestone & 0.73 \\
\hline Mole-Champeh & $\begin{array}{l}\text { Ml- } \\
\text { Cpm }\end{array}$ & Marly Limestone & 0.72 \\
\hline Quaternary & Q & $\begin{array}{l}\text { Recent Alluvial } \\
\text { Deposits }\end{array}$ & 1 \\
\hline Sachun & $\mathrm{Sa}$ & $\begin{array}{c}\text { Marl, Dolomite, } \\
\text { Gypsum }\end{array}$ & 0.33 \\
\hline Salt Plug & $\mathrm{Sp}$ & Salt Plug & districted \\
\hline Tarbur & $\mathrm{Tb}$ & Limestone & 0.75 \\
\hline
\end{tabular}

Table 2. Fuzzy membership function for lithology layer

\subsection{Data integration}

After each data layer has been weighted by assign Fuzzy membership functions, all input maps were converted to a raster grid with a cell size of $50 * 50 \mathrm{~m}$ based on the value of Fuzzy membership which each of them was assigned. Fuzzy sum, product operators were computed according to the 1 and 2 formula (An et al., 1991). Finally, fuzzy $\gamma$ Operator was applied with the value of $\gamma=0.95$.

Fuzzy Algebraic Sum

$$
\mu_{S U M}(\chi)=1-\prod_{i=1}^{2} \mu_{i}(\chi)
$$

Fuzzy Algebraic Product

$$
\mu_{P R O D U C T}(\chi)=\prod_{i=1}^{2} \mu_{i}(\chi)
$$

Fuzzy $\gamma$ Operator 


$$
\mu_{\gamma}(\chi)=\left[\mu_{S U M}(\chi)\right]^{\gamma} \times\left[\mu_{P R O D U C T}(\chi)\right]^{1-\gamma}
$$

By using the fuzzy operator "OR and AND", only one of the contributing fuzzy sets has effect on the resultant value. The fuzzy algebraic sum and product operators make the resultant set larger than or equal to the maximum value and smaller than, or equal to the minimum value among all fuzzy sets. Meanwhile, the resultant set that is combined by the fuzzy $\gamma$ operator has the value between that of the fuzzy algebraic product and the fuzzy algebraic sum operator.

\section{CONCLUSIONS}

In this paper, Fuzzy logic approach was used in a suitable combination of slope, elevation range, drainage density, fracture distance and lithology layers to ground water exploration. To combine various spatial data, we applied fuzzy product and sum operators. Also, the fuzzy $\gamma$ operator with the value of $\gamma=$ 0.95 was tested. Figure 6 shows fuzzy map of ground water exploration. Result indicated that most of the nearest area to anticline has very high, high and moderate potential especially in the SE direction. Further results show, the most appropriate area to drilling is the region with Quaternary formation which is approximately, in the $200 \mathrm{~m}$ from the anti-cline. Very high potential area, generally, are found in the land with less than $4 \%$ slope and less than 400 meter from sea level. In verse, very low potential area are characterize by harder lithology such as Dolomite, Gypsum which covers land with more than $30 \%$. Finding out an accurate method which accelerates processing for determining the location of groundwater before drilling is an effective solution leading to save budget and time. In this paper, we conducted a fuzzy set theory, as a knowledge driven approach for map combination using the fuzzy $\gamma$ operator with a value of $\gamma=0.95$. The final results indicate the most suitable formation for drilling.

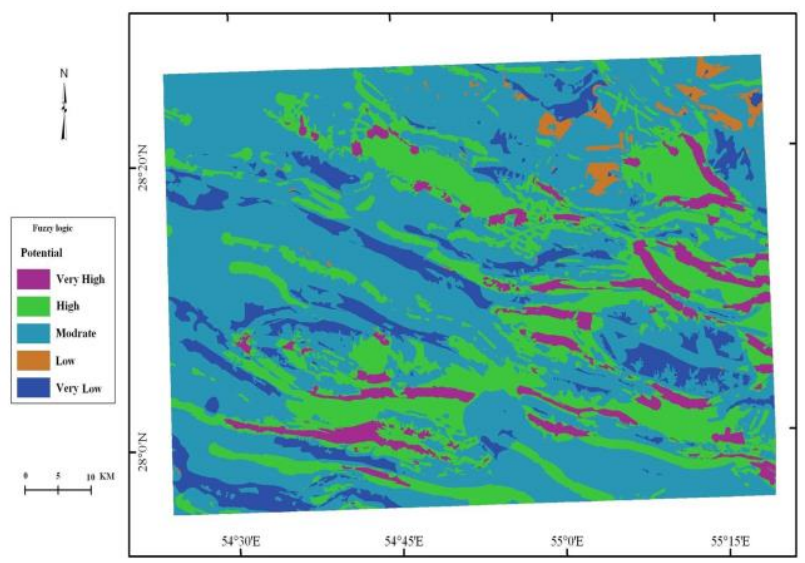

Figure 6. Groundwater potential map using fuzzy logic approach

\section{REFERENCES}

Acreman, M., 2000. Wetlands and Hydrology, Conservation of Mediterranean Wetlands, 10. Tour du Valat, Arles (France).

An, P., Moon, W.M., Rencz, A., 1991. Application of fuzzy set theory to integrated mineral exploration. Canadian Journal of Exploration Geophysics, 27(1), pp.1-11

Assimakopoulos, J.H., Kalivas, D.P., Kollias, V.J., 2003. A GIS-based fuzzy classification for mapping the agricultural soils for N-fertilizers use, The Science of the Total Environment, 309, pp. 19-33.

Enea, M. \& Salemi, G., 2001. Fuzzy approach to the environmental impact evaluation, Ecological Modelling. 136, pp. 131-147.

Ghayoumian, J., Ghermezcheshmeh, B., Feiznia, S., Noroozi, A.A., 2007. Application of GIS techniques to determine areas most suitable for artificial groundwater recharge in a coastal aquifer in southern Iran, Journal of Asian Earth Sciences, 30, pp. 364-374.

Ghayoumian, J., Ghermezcheshmeh, B., Feiznia, S., Noroozi, A.A., 2005. Integrating GIS and DSS for identification of suitable areas for artificial recharge, case study Meimeh Basin, Isfahan, Iran. Environmental Geology, 47 (4), pp. 493-500.

Gorsevski, Pece V., Gessler, Paul E., Jankowski, P., 2003. Integrating a fuzzy k-means classification and a Bayesian approach for spatial prediction of landslide hazard. Journal of Geographic System, 5, pp. 223-251.

Han, Z., 2003.Groundwater resources protection and aquifer recovery in China. Environmental Geology, 44(1), pp.106-111.

Kampichler, C. \& Barthel, J. \& Wieland, R., 2000. Species density of foliage-dwelling spiders in field margins: a simple, fuzzy rule-based model. Ecological Modelling, 129, pp. 87-99.

Klein, L., 1999. Sensor and Data Fusion Concepts and Applications. SPIE Optical Engineering Press, Bellingham, Washington.

Kollias, V.J., D.P., Kollias, 1998. The enhancement of a commercial geographical information system (ARC: INFO) with fuzzy processing capabilities for the evaluation of land resources, Computers and Electronics in Agriculture, 20, pp. 79-95.

Krishnamurthy, J., Srinivas, G., 1995. Role of geological and geomorphological factors in groundwater exploration: a study using IRS LISS data. International Journal of Remote Sensing, 16 (14), pp. 2595-2618.

Maidment, D. R., GIS and Hydrologic Modelling, 1991. The First International Conference/Workshop on Integrating Geographic Information Systems and Environmental Modelling. Boulder, CO.

Metternicht, G., 2001. Assessing temporal and spatial changes of salinity using fuzzy logic, remote sensing and GIS. Foundations of an expert system. Ecological Modelling, 144, pp. 163-179. 
Mitra, B., Scott, H.D., Dixon, J.C., McKimmey, J.M., 1998. Applications of fuzzy logic to the prediction of soil erosion in a large watershed. Geoderma, 86, pp. 183-209.

Moore, I. D., Turner, A. K., Wilson, J. P., Jenson, S. K., Band, L. E. GIS and Land Surface-Subsurface Process Modelling, (1991). The First International Conference/Workshop on Integrating Geographic Information Systems and Environmental Modelling. Boulder, CO.

Nisar Ahamed, T.R., Gopal Rao, K., Murthy, J.S.R., 2000. Fuzzy class membership approach to soil erosion Modelling. Agricultural Systems, 63, pp. 97-110.

Nisar Ahamed, T.R., Gopal Rao, K., Murthy, J.S.R., 2000. GISbased fuzzy membership model for crop-land suitability analysis. Agricultural Systems, 63, pp. 75-95.

Nunnari, G. \& Nucifora, A. \& Randieri, C., 1998. The application of neural techniques to the modelling of time-series of atmospheric pollution data. Ecological Modelling, 111, pp. 187-205.

Tangestani, M.H., Moore, F., 2003. Mapping porphyry copper potential with a fuzzy model, northern Shahr-e-Babak, Iran, Australian Journal of Earth Science, 50, pp. 311-317.

UNEP, 2002. Global Environmental Outlook 3, Nairobi, Kenya.

Zadeh, L., 1965. Fuzzy sets. Information and Control, 8, pp. 338-353.

Zimmermann, H.J., 1996. Fuzzy set theory and its applications. Kluwer Academic Publisher. 